\title{
Thematic Transgressions and Formal Innovations in Edna O'Brien's The Country Girls Trilogy and Epilogue
}

\author{
María Amor Barros-del Río \\ University of Burgos, Spain
}

Copyright (c) 2018 by María Amor Barros-del Río. This text may be archived and redistributed both in electronic form and in hard copy, provided that the author and journal are properly cited and no fee is charged for access.

\begin{abstract}
The paradigmatic literary work of Edna O'Brien, The Country Girls Trilogy and Epilogue (1986) narrates the coming of age of two young women from rural backgrounds in the Ireland of the mid-twentieth century and their progressive entry into an adult world, passing through the capital, Dublin, to finally leave their country and arrive in London. Censured in its day, the trilogy is now acknowledged as a feminine Bildungsroman, above all, because of its open allusions to the awakening of female sexuality. However, most criticism has overlooked the political implications of its central theme, as well as the structural and formal innovations that the author employs to represent the impossibility of a feminine Bildung form. Polyphony, fragmentation, and ultimate disintegration are some of the elements that evidence the need to reconsider the place of the trilogy within the panorama of Irish literature.
\end{abstract}

Key Words. Edna O'Brien, Transgression, Narrative Voice, Anti-bildungsroman.

Resumen. La obra paradigmática de Edna O'Brien, The Country Girls Trilogy y Epilogue (1987) narra la infancia de dos niñas de la Irlanda rural de mediados del siglo XX y su progresiva entrada en el mundo adulto, pasando luego por la capital, Dublín, para finalmente abandonar su país y afincarse en Londres. Censurada en su día, principalmente por sus abiertas referencias al despertar de la sexualidad femenina, la trilogía ha sido ya reconocida como novela de aprendizaje femenina. Sin embargo, la mayoría de las críticas han pasado por alto las implicaciones políticas de su tema central, así como las innovaciones estructurales y formales que emplea la autora para representar la imposibilidad de una emancipación femenina. Un análisis detallado de estos elementos (polifonía, fragmentación, desintegración) demostrará la necesidad de reconsiderar sus méritos dentro del panorama de la literatura irlandesa.

Palabras clave. Edna O’Brien, transgresión, voz narrativa, anti-bildungsroman. 


\section{Introduction: A Scandalous Trilogy in the Irish Literary Tradition}

The female experience of childhood and subsequent entry into the adult world was imprinted in the Irish literary tradition for the first time in 1960, with the publication of The Country Girls. ${ }^{1}$ The "scandalous" (Woodward; Dennison; Schiff) first novel by Edna O'Brien narrates the story of two young women, Cait and Baba, who leave the village of their birth to go to a convent boarding school. After some years under the nuns' discipline, they both manage to get themselves expelled in order to go to Dublin to work. The sequel, The Lonely Girl (1962) (renamed Girl with the Green Eyes two years later) narrates the romantic lives of these "girls from the country" in the capital, where they expect to live out the experiences they had been denied in the rural environment. Its last chapter describes both young women leaving Dublin behind as they move on to London. The central theme of the last book in the trilogy, Girls in their Married Bliss (1964), portrays the breakdown of both women's marriages, followed by the protagonist's attempts to make sense of their lives. ${ }^{2}$ In 1986, The Country Girls Trilogy was edited in a single volume to which the author added an Epilogue. In the 20 pages of the latter, Baba retrospectively narrates the story of both women over the past 20 years, alternating between one story and the other, while she waits for the train that will return Kate's body. With a strong autobiographical component, O'Brien manages to convey the private world of Irish women in the central decades of the twentieth century, from childhood, through adolescence to marriage, a theme that had never before been expressed in Irish literature (O'Callahan 171). It was praised and criticized in equal measure. Critics have considered the trilogy as a space where the personal becomes public and where subjectivity, authority, and agency acquire a central character (Harte). Irish literature had already spawned works on growth and maturity, A Portrait of the Artist as a Young Man (1916) by James Joyce being the most influential modern Bildungsroman (Cahalan, Double Visions). Kate O'Brien, in her female version, The Land of Spices (1941), also showed the process of emancipation of a women supported by an adult female figure.

The formal experimentation found in The Country Girls Trilogy and Epilogue has been noted in several studies (Byron; St Peter). However, this innovation has not always been well received and, for some critics, it may have been a reaction to the accusations of frivolity that have always been levelled at Edna O'Brien as a woman (Woodward) and as a writer (P. O'Brien; Pelan), an image accentuated, to a certain degree, by her open references to the body and to female sexuality (Rooks-Hughes; Thompson; Villacañas). The inherent political stances of O'Brien's works, which diverge from the nationalist and Catholic principles of the Ireland of her birth, have also been the subject of study and a cause for censure and defamation (Colletta and O'Connor; Drisceoil; Huang; Ingman).

So much controversy was generated by this author and her literary production that unusual descriptions were published, such as: "She is the writer run out of County Clare, also a monster, a nymphomaniac, a nutcase, a social climber, a spoiler of neighbourhoods and children, a purveyor of clichés, a romance novelist, an Amazon, a Jezebel, a political naïf" (Schiff). Despite this public perception, in the key work Inventing Ireland critic Declan Kiberd asserted that she is "the writer who made many of the subsequent advances in Irishwomen's writing possible" (566), and the fourth and fifth volumes of The Field Day Anthology of Irish Writing are dedicated to literature for women, presenting a more holistic vision, linking the author and her literary production to questions of various sorts, such as censure, nationalism, Catholicism, and education, as well as female sexuality (Bourke et al.). Be that as it may, this prolific author of novels, stories, theatre, biographies, and poems has achieved a strong reputation. Her work continues to be enthusiastically studied (Greenwood; Laing, Mooney, and O'Connor; Colletta and O'Connor) and her name remains indelibly 
linked to the awakening and sexuality of those country girls. In the light of all these considerations, this essay situates the trilogy in its postcolonial context and centres its analysis on the thematic, structural, and formal innovations that Edna O'Brien writes into The Country Girls Trilogy and Epilogue as a female Bildungsroman with the objective of demonstrating that the trilogy deserves reconsideration within the Irish literary panorama.

\section{Reconsideration of the Bildungsroman in the Irish Context}

Inspired by the principles of the Enlightenment, the concept of the Bildungsroman was incorporated into academic discourse through the work of the German philosopher Wilhelm Dilthey (Becerra), who identified a specific genre, taking Goethe's novel Wilhelm Meister's Apprenticeship (1795-96) as a model, in which reason and morality attain perfection through education. The Bildungsroman is a literary form symbolically linked to Western modernity, to the development of individuals and their efforts to explain "the meaning of life" (Moretti 13). Thus, this genre is framed within the category of a "novel of learning" (Morgan 183-84) that shows the evolution of the leading character or Bildungsheld, "generally a child or a young person" (Fernández Vázquez 14) going through a process of growth, maturity, and integration into the world. According to various scholars, the Bildungsroman could serve as an instrument to approach the relationships between individual and society and the ways in which social, cultural, and ethical values are inculcated and transmitted (Moretti; Fogarty). However, in a postcolonial context, such as Ireland, this recipe is problematic, because the political ideology of the state and the ecclesiastical apparatus intervene in the formation of individual identity, restraining the emancipatory process to certain conventions that are strongly linked to specific models of citizenship explicitly stated in the Irish Constitution of 1937.

These conventions would explain the scarcity of novels of emancipation from female childhood, according to Dougherty (50), which began to be possible in the 1960s and 1970s, when external cultural influences through communications media, increasing migratory flows, and economic change initiated by the government were transforming the country (Fagan). Several scholars have studied how the postcolonial Irish Bildungsroman emerged as a discourse of resistance and show evidence of the constraints on the emancipatory process in the framework of the new Irish Free State (Hardin; Smyth; Nolan; Mansouri). However, The Country Girls Trilogy was developed within the framework of strong Catholic and conservative nationalism, reinforced by a protectionist economic policy that from an ideological point of view exerted strong pressures on the female population, and in particular on mothers as the pillars and safeguards of Irish traditions (O'Leary 21). So, when the novels and epilogue were published together in 1986, the journey of initiation served as a means of emancipation for the young female characters, but also as a means of subversion of the asphyxiating insularity that Ireland, in its nationalist fervour, was living through. That context meant that the epic journey could never be successful in Dublin and it was necessary to leave Ireland, to flee the ideological restrictions of the country.

Although the progressive physical distancing from the place of origin is a traditional feature of the Bildungsroman structure, it is also a metaphor for these young women's estrangement from traditional Irish values in the trilogy, a process that is exemplified in the name change by which Cait becomes Kate in the second book. This Anglicization, thought up by her husband Eugene, symbolically deprived Cait of her Irish origin: "Caitleen was too 'Kiltartan' for his liking" (Lonely Girl 202) and from that moment it is spelled Kate to the end of the story. However, the geographic distance of England is not sufficient to permit the success of the Bildungsroman, as both protagonists discover that their lives in London would continue to be marked by the Irish education and culture from which they came, and their 
disappointing destinies were still tied to essentially patriarchal norms that remain inalterable in all societies. All of these circumstances confirm an extrinsic difficulty with the development of the emancipatory process of the Bildungsheld (the hero) to which the distancing of the author from her country may be added, as well as her "constant negotiation with physical and emotional displacement" (Barros-del Rio 1504), and the incipient signs of modernity that were already appreciated in Ireland. In view of all of this, The Country Girls Trilogy finds its context in the various literary expressions of non-conventional emancipation that were emerging in the decade between 1960 and 1970. In 1965, John McGahern's The Dark was published, considered the best and the most impressive Bildungsroman after Joyce, and one of the most disturbing examples of the genre (Cahalan, "Female and Male Perspectives"; Cronin; Devine). Other examples include The Woman's Daughter (1987) by Dermot Bolger and Black List, Section H (1971) by Francis Stuart, which not only portrayed Irish life, but instigated a review of native values and history, presenting a dialectical criticism to counter the limitations enforced by the ideological apparatus of the Irish state and the Church (Mansouri).

\section{Structural and Formal Alteration of the Novel of Female Emancipation}

Another discordant factor needs to be added with regard to the traditional ingredients of the novel of male emancipation. If the male Bildungsroman has traditionally had a linear structure that leads the main character from a point of origin to a defined end, this arrangement is problematic for the female emancipatory process. If male development is characterized by an internal process involving the reconciliation of personal and social demands, in the female Bildungsroman, the negotiation of gender and identity in personal and social contexts is a permanent source of conflict. The heroine usually has a more difficult start, as she must break with traditional structures and leave the family circle to enter society. This painful start is not suffered by the masculine hero whose gender implies all types of potential development in both private and public spheres. The heroine, in contrast, has received instruction within the household with regard to the rituals of human relations so that she may reproduce the life of her mother. The challenge of the female Bildungsroman, therefore, means not only an intrusion into a world in which she is not considered as an active individual, but firm opposition to the subordinate roles that are expected from her within the heterosexual relationship.

If the process of character development and entry and integration into the outside world constitute the centre of attention in the male Bildungsroman, in the novels of female emancipation, the sovereignty of the central character is not always evident (Fraiman). Therefore, the masculine model presents an integral protagonist who is frequently alone against the world, which he must come to understand and succeed in dominating in order to attain success in the end. In contrast, female protagonists are usually more susceptible to the influence of society, history, and other individuals. Structurally, the male plot usually finishes when the protagonist reaches a level of affinity between his own desires and the social norms, finally feeling himself in harmony with these structures. In the female case, the main character moves between patriarchal structures that offer no response to her personal necessities, such that no dialogue is possible. Finally, when the male hero reaches maturity, he generally returns home to establish himself with success, considering that his journey has come to an end. This ending in the female version is revealed as disappointing or incomplete. Sometimes, returning home is not possible because it would bring neither success nor social acceptance.

These asymmetries make it necessary to alter the narrative structure and to employ resources that resolve the story of the female Bildungsheld, which makes necessary 
experimentation and a departure from the traditional models to align the genre with female needs (Ferguson; Ferreira Pinto). As Dougherty has pointed out, novels of emancipation from female childhood are "formally or stylistically peculiar" (50). The Country Girls Trilogy and Epilogue is a paradigmatic example of that peculiarity, in as much as it alters one of the key elements of the emancipatory model. Here the protagonist is not a young man, but two girls. The nature of the trilogy necessitates the use of two main characters, one in some ways the alter ego of the other. As will be seen, this literary technique, through the formal alteration of the traditional Bildungsroman in an effort to renegotiate the scheme associated with the genre, permits the expression of the complex experience of female emancipation and failure.

\subsection{Use of the Alter Ego}

The historic period in which the plot of the trilogy is situated was marked in Ireland by strong reactionary policies based on tradition and a strict moral code, isolation, and socioeconomic and cultural immobilism which was extremely restrictive in rural areas. It is the impossibility of articulating an emancipatory adventure for one girl alone, imposed by these circumstances, which led Edna O'Brien to create two main protagonists, one the alter ego of the other, for the sake of credibility. Notably, O'Brien is not alone in the use of twin characters to illustrate processes of female development. It is enough to mention a few paradigmatic and contemporaneous novels, such as A Summer Bird Cage (1969) by Margaret Drabble or The Game (1967) by A.S. Byatt, both considered to be "dual Bildung" (McWilliams 21).

A worthy precedent in Irish literature, in addition to the aforementioned work of Kate O'Brien, The Land of Spices, is Grania (1892), in which Emily Lawless presented two characters united in sisterhood: Grania and Honor. Likewise, the Anglo-Irish writers Somerville and Ross portrayed the fictional duo of Charlotte Mullen and Francie Fitzgerald in The Real Charlotte (1894).

Edna O'Brien's trilogy employs literary strategies that change and mould the developmental process of her narrative voices. From the very first lines, the narration of the trilogy is presented through the "I" of the first-person narrator, leading protagonist Caithleen Brady, who constantly seeks other people as points of support and instruments of development in her search for other characters as anchors and sources of development in her growth. Among them all, the most important is Baba Brenan, the childhood friend, to whom she will be joined in a life-long relationship based on fear and dependency. ${ }^{3}$

The nature of this symbiosis is explained by the compensation between the two extremes, as the author has explained: "I decided to have two, one who would conform to both my own and my country's view of what an Irish woman should be and one who would undermine every piece of protocol and religion and hypocrisy that there was" (P. O'Brien 13). Through this strategy, O'Brien achieves a perfect balance in which one character complements the other physically - "Her hair was newly set, so that it curved in soft black waves that lay like feathers on the crown of her head. I was raging. Mine was long and loose and silly looking" (Country Girls 143) - and, on the psychological plane, in a love-hate relation that would bind them forever, as opposite extremes: "Coy, pretty, malicious Baba was my friend and the person whom I feared most after my father" (Country Girls 14). Without a doubt, this polarity reflects the semiautobiographical nature of the work and the life experience of the author, who even affirmed: "I think that [the inspiration for Baba] was partly my other person, my alter-ego. I had a sort of streak of submersed rebellion in me always, which I never let out, unfortunately; I was really too frightened, too meek" (qtd. in Eckley 67). This relationship of dependency and complementarity is necessary for the emancipatory project, as McMahon has pointed out: "Between the two girls, the one whimsical and literary to the point of bathos ..., the other blasé but practical ... there is an 
ideal friendship, and there emerges a blueprint for a woman who could meet the world and not be defeated by it" (85). The use of the alter ego has also been seen as a reflection of intrinsic contradictions within the individual through denominations such as "I and Not-I" or "the id and ego of a divided self" (Dunleavy and Lynch 99). All these ideas converge in the projection of a plural, diverse, but shared experience. The use of a "multiple individual", a phenomenon that has been detected by DuPlessis in other twentieth-century narratives, now defies the domineering ideological dictates of the young Irish Free State. The transgression of the dictates of both state and Church begins with the disparate but complementary nature of the main characters: "Baba was sex and Cait was romance" (Carlson 71), a duality that dismantles moral dictates and simultaneously represents a barrier to the survival of the single unitary subject that is usual in the Bildungsroman.

But the audacity of Edna O'Brien transcends the thematic innovation and should be understood as a stylistic and formal experimentation that has exercised a significant influence on more recent writers. Miriam Dunne recognizes the impact of the trilogy, which may be appreciated in the similarities between O'Brien's Baba and Caithleen and the main characters Mags and Marian in her own novel Blessed Art Thou a Monk Swimming (Moloney and Thompson 49). Catherine Brady has similarly expressed her admiration for O'Brien (Moloney and Thompson 157). In short, the use of two main characters as alter egos in the female emancipatory process, which Edna O'Brien inaugurated, implies a formal innovation that, as will be seen, also impacted on structural and stylistic novelties that have often passed unnoticed.

\subsection{Polyphony: A Form of Thematic Transgression}

One key aspect for the re-evaluation of The Country Girls Trilogy is found in the interlaced narrative voices and their development throughout the plot, to the point where they become a dynamizing element of the formal and structural variations. Edna O'Brien makes use of this strategy to profile the different emancipatory processes of her main characters: Cait is the protagonist and the first-person narrative voice of the two first books, so that it is easy for the reader to identify with her youth and innocence. This narrative homogeneity is seen to be progressively altered when Baba becomes the omniscient first-person narrator of chapters 1 , 6,7 , and 10 of the third book. In this third volume, an abrupt emotional change is expressed in the form of derision of the authority they have conquered, since the developing presence of Baba's narrative voice manages to undermine the textual authority of Cait. So, her progressive weakening is compensated by the pragmatic vision of Baba who, in the Epilogue, will be the only survivor of the emancipatory process.

This alternation between two points of view that are independent of each other responds to the need to express the internal division of the narrator in the first-person, to show two vital and equally unsatisfactory experiences. As may be expected, this formal change also involves a stylistic change: Baba's personality is expressed in dynamic and expressive turns of phrase, in accordance with her character; through the frequent use of short utterances; and the inclusion of colloquialisms in the course of the narration or the erroneous use of certain verb forms, for example. Cait's voice, more measured, precise, and descriptive, prevails in the narrative of the first two books. This stylistic chameleon-like aspect demonstrates the skilfulness of the author in constructing different characters and expressing the diversity of the female life-experience.

Additionally, the use of various narrative voices also serves to project a political stance in clear defiance of the ideological dictates of the Ireland of the time. Through the innocent Cait, the first and second books present the misery and grandeur of isolated rural Ireland: the abusive alcoholic father, the self-sacrificing mother totally devoted to her child, 
and the exuberant background of the Irish landscape enveloping it all; the sobriety and the hypocrisy of religious education; inhospitable Dublin with its grey streets and its literary atmosphere; romantic love and sexuality, and marriage as the only means to achieve social standing. These and other issues appear scattered throughout the trilogy through brief scenes and distinctive motifs that illustrate scenes of daily life but have enormous impact (Coughlan). Through the use of first-person narration, O'Brien facilitates the identification of the reader with the narrated experiences, which are to a certain extent those of the author, which reinforces the autobiographical and underlying truth that sustains the plot. At the same time, when presenting all of these questions with the candour of a "country girl", O'Brien once again attacks the ideological foundations of an Ireland unable to confess to its own weaknesses: both The Country Girls and The Lonely Girl use the main protagonist's innocence to dismantle the ideological pillars of the new Irish Republic. Recently, D'hoker underlined O'Brien's influence on the work of Claire Keegan, particularly in the use of the female narrative voice in the first-person, acknowledging O'Brien's role in introducing this stylistic innovation to the panorama of Irish literature.

In the third volume, O'Brien incorporates a new narrative voice, as noted above, that of Baba, introducing more stylistic and structural novelties. It has been said of Girls in their Married Bliss that it has an angry, sordid tone, is written in a careless and fragmented way, and is characterized by the loss of innocence by main characters who appear to have been "the hook" of the earlier novels (McMahon); it has even been used to qualify a "dark period" in Edna O'Brien' work (Popot 274). Certainly, this volume seeks to break with the well-worn cliché of marital bliss, which implies that both its form and content are uncomfortable. Girls in their Married Bliss returns to the story of Kate and Baba when they are both married and living in London. Kate's marriage to Eugene appears from the start to be somewhat forced by an unexpected pregnancy. The incompatibility of characters and the disillusion of both leads Kate to enter into an extra-marital relationship with a married man that will finally result in divorce from Eugene and a solitary existence in London. Disillusion with the conjugal ideal finally results in a nervous breakdown. Psychiatric treatment, an unsatisfactory sexual adventure, and unsuccessful litigation over the custody of her only child finally make Kate submit to sterilization. Baba, for her part, marries a man in a good social position for whom she feels no love. She calls herself "the sacrificial lamb" (Girls 386) on the day of her wedding. Hers is a marriage overshadowed by violence and frustrating sexual relations. Baba's own diverse extra-marital relations end with an unwanted pregnancy that her husband feels obliged to accept to avoid scandal.

The last scene of this third book shows Baba visiting Kate in the private clinic after the sterilization, an act that, on the one hand, captures for Kate a high degree of resistance and rebelliousness, any possibility of her giving life definitively ended and, on the other, an expression of self-defence against the legal system that had snatched custody of her daughter from her. ${ }^{4}$ Frustration and bitterness are felt by both characters, illustrated through open allusions to domestic violence: "An occasional blow from her husband gave to one or the other of those green eyes a permanent knowingness, as if at twenty-five she realized what life was all about" (Girls 390). Legal structures of oppression are also addressed: "She asked why she hadn't been consulted, and the clerk said that a mother's signature was not necessary for such a thing" (Girls 503). Medical care is also identified as a mechanism of exerting power over women: "'Relax,' he said, sort of bullying then. Relax! I was thinking of women and all they have to put up with, not just washing nappies or not being able to be high-court judges, but all this. All this poking and probing and hurt. And not only when they go to the doctors" (Girls 473). These passages exemplify the magnitude of a gender-biased system that none of the protagonists can fight, as Baba finally admits: "the conspiracy was too enormous, the whole machinery too thorough" (Girls 504). 
This third volume constitutes a point of inflexion in which the novel uses of the alter ego and narrative voices coincide to illustrate the failure of the conjugal relationship as the ultimate end of the female quest. Through the fall of the myth of romantic love, the reader's confidence in the narrator of the first two books is also shaken. The intermittent entry of Baba as a pragmatic narrator prepares the reader to question the innocent and lyrical perspective of Kate, and finally reveals her as an "unreliable narrator" (Culler 91), because of her limited point of view and limited knowledge. In this shift, the third book also makes sporadic use of an omniscient narrative voice with the purpose of establishing the distance needed to present scenes of profound transgression, such as the sterilization of Kate, or reflections to which neither of the protagonists is capable of giving a response, thereby illustrating the disorientation that Adrianne Rich has called "wandering in the wilderness" (246): "It was odd for Baba to see Kate like that, all the expected responses were missing, the guilt and doubt and sadnesses, she was looking at someone of whom too much had been cut away, some important region that they both knew nothing about" (Girls 508).

Formally, Baba's intermittent narrative voice anticipates the fate awaiting Kate. The alternating narrators, materialized here in the disappearance of Kate as the first-person narrator, are illustrative of her progressive deterioration and vanishing. She now finds it immensely difficulty to express her personality and her history, essential in the two earlier books, with the same intensity and her inability to speak in some scenes symbolizes the lack of self-control over herself and her own story. Also, the inclusion of temporal jumps in which the narrative voice alternates scenes both past and present suggests a predestined end to the female emancipatory process and encourages brief attempts to settle into free narration following the flow of thoughts, without doubt the fruits of the author's affection for Joyce, as illustrated by some passages bordering on stream of consciousness: "She thought, He knows, he knows. If only he'll give me this last chance, I'll change, reform, make myself so ugly that I will be out of the reach of temptation" (Girls 390). This style suggests that O'Brien was immersed in progressive stylistic experimentation throughout the trilogy which, accompanied by significant thematic innovation, finds its zenith in the sordid separation of the two protagonists.

A further step in the formal experimentation can be appreciated in the Epilogue, a brief story that attempts retrospectively to cover the intervening 20 years of the protagonists' lives. ${ }^{5}$ The only narrative voice in first person comes from Baba, an omniscient narrator who in an falt tone recalls the most intimate conversations and thoughts of the two leading characters in continuous sequences. At a certain point, the omniscient narrative perspective of Baba comes to an end and the intentionality of the author appears to point towards an obligatory complicity with the reader. The use of the second person "you" has been interpreted as a way of imposing an engagement with a gender perspective upon both the reader and the narration (Byron). ${ }^{6}$ The earlier narrative dynamism continues but with less urgency and more careful language perhaps linked more to the maturity reached by the sole survivor. The death of Kate, which had been hinted at since Chapter 8 of Girls in their Married Bliss, ${ }^{7}$ even reaches a eulogizing tone in the Epilogue: "Oh, Kate, why did you let the bastards win ... why buckle under their barbaric whims?" (513). The Epilogue suggests the existence of a letter that Kate had written before her death. That letter, never found, would reveal the untold story behind the plot, the unspeakable facts and emotions of the Irish female experience. But Baba concludes that it is a letter that still cannot be read out aloud because the world is not ready to understand it: "there are some things in this world you cannot ask, and oh, Agnus Dei, there are some things in this world you cannot answer" (Epilogue 532). The Epilogue twice makes reference to emptiness as Kate's greatest fear, confirming in some way the inevitable development of a psychologically unstable ego in stark contrast to the 
traditional evolution of a coherent subject (Abel, Hirsh, and Langland), which definitively illustrates the impossibility of the female emancipatory process for Irish women of the 1960s.

The expected thematic progression as difficulties are overcome, inherent to the traditional Bildungsroman, are truncated in the Epilogue. Kate drowns herself in a scene that recalls her mother's destiny in the first book and underlines the repetition of failure. Structurally, the incomplete circularity of the trilogy stands in radical opposition to the linearity that characterizes the traditional structure of the male Bildungsroman. The uncertainty of the female emancipatory process reaches its peak in the Epilogue, leaving the arrival of Kate's lifeless body at the station in suspense and offering as the sole response Baba's assumptions on the degree of intentionality in her death.

\section{Conclusions}

The Country Girls Trilogy and Epilogue is a work whose formal innovation derives from the impossibility of the female character following the same stages of development as the male character within the traditional structure of the Bildungsroman genre. From an historical point of view, the decades of the mid-twentieth century were dominated by strong Catholic nationalism that circumscribed female behaviour to domestic chores and maternity. To this end, a series of legal, moral, and economic mechanisms were rolled out to limit women's scope of action. In this context, the trilogy incorporates a discourse of resistance that emphasizes the disenchantment, the frustration, and finally the rejection of that female model, taking form through the daily experiences of the two main characters. In this way, the journey of emancipatory initiation manifests itself in a progressive physical and emotional distancing at the same time as it defies traditional values and makes the structural limitations of the emancipatory process evident within the framework of the young Irish Free State. Necessarily, this estrangement is coupled with a structural alteration of the linear progression of the Bildungsroman. If we are facing a chronological succession in the first two books, the third and the Epilogue offer an increasing use of temporal leaps and narrative voices that alter the earlier unity. Such unity, which found its origin in the perfection of the world of childhood, disappears with the death of Kate's mother and Kate sees no other choice than to initiate an epic journey that will gradually distance her from the ideological dictates imposed by the Irish state. The progressive distancing of the family environment is a movement "toward increasing exile, loneliness, and loss" (Cahalan, Double Visions 59) and ends in total annihilation, in death.

As a consequence of this dystopian female universe, the initial unity of the narrative in the two first books is upset by the introduction of second narrator in the third book. The use of different points of view constitutes one of the key aspects that makes the trilogy a nonconventional Bildung, because it describes the process of destruction or disintegration of the principal character, and not her progressive construction, emancipation, and integration as might be expected. Thus, we may affirm that The Country Girls Trilogy and Epilogue alters the parameters of the traditional Bildungsroman by positioning the woman hero on a path to destruction that will be revealed through various signs, such as the loss of speech, the progressive fragmentation of her personality, the annihilation of intellectual and physical potentialities, and finally her death. The use of two protagonists, one the alter ego of the other, might be expected to endow the two characters with very broad capabilities for negotiation with the world. On the contrary, however, their progressive separation from their physical and ideological roots has repercussions in the worsening instability of the egoistic structure of Cait, the protagonist of the two first books, whose destructuring takes the form of the splitsubject and who is progressively in need of a complementary voice contributing the security she lacks. In this sense, the incorporation of various narrative voices attacks the unity of the 
growing female protagonists and, by extension, the symbolic united front of Irish womanhood, thereby expressing a plurality of experiences that faces serious obstacles to expressing itself. The use of the alter ego is a necessary strategy to express a desire of female agency that in this trilogy is truncated, expressing in this way the impossibility of female agency in the postcolonial context of mid-twentieth-century Ireland.

All these elements make it difficult to categorize this work, as it is in open resistance to the traditional (male) Bildungsroman structure, which necessarily entails a series of alterations. Its structural, formal, and thematic innovations have seen the trilogy labelled variously a "negative romance" (Greenwood), an "anti-bildungsroman" (McMahon), and a "double-bildungsroman" (Cahalan, "Female and Male Perspectives"; Double Visions), but none of these definitions fully covers the complexity of its meaning and the particularity of the stylistic devices used. Its uniqueness is found in the use of two divergent heroines, one who falls victim to insanity and destruction after rejecting societal conventions, and another who survives at the cost of accepting subjection to a "repressive normality" (Abel, Hirsh, and Langland 12). That said, the trilogy would better fit the concept of "truncated bildungsroman" attributed to postcolonial novels with similar characteristics (Fernández; Ferreira).

Be that as it may, The Country Girls Trilogy and Epilogue deserves a prominent place in Irish literature, as it offers a new form of expression of the female emancipatory process illustrated through a multiplication of narrative voices and the eventual disintegration of the principal character. Without doubt, it is a brave and risky work that opened new horizons in its day for the exploration of the Irish female experience.

\section{Notes}

\footnotetext{
${ }^{1}$ Despite the rigid censure and the scandal that its publication caused in Ireland, the success of that first novel won the Kingsley Amis Award for Edna O’Brien in 1962, and brought her fame as a magnificent writer of lyrical prose (Cahalan; Roth; Kersnowski).

${ }^{2}$ Perhaps due to the character development of the protagonists throughout the trilogy, Girls in their Married Bliss was not well received by O'Brien's readership or the critics. Only a few saw her innovative achievement. In particular, the critic Dermot Bolger pointed to the final passage, in which Kate agrees to sterilization in hospital, affirming that O'Brien had marked a new height in the Irish literature and was ahead of her time (xxii). ${ }^{3}$ A replica of the dependency between the characters may be seen in O'Brien's subsequent novel, Zee \& Co (1971), in which Stella and Zee reproduce Cait and Baba, respectively. In Night (1972), the technique of the alter ego was again employed by O'Brien.

${ }^{4}$ It is worth pointing out that Edna O'Brien added this episode in 1967, in the revised edition of Girls in their Married Bliss.

${ }^{5}$ The formal and stylistic novelties of the Epilogue have attracted various studies, among others Haule, Pelan, and Byron.

${ }^{6}$ In A Pagan Place (1970) and Night (1972), Edna O'Brien had already made use of a narrative voice in the second person, a formal experimentation that might have had some influence on the Epilogue.

${ }^{7}$ Frustrated suicide is a recurrent element in the fiction of Edna O'Brien through which she seeks to reinforce the feeling of self-effacement after the loss of a loved one or object, thereby underlining the protagonists' dependency upon the "other", as may be appreciated in the stories "The Love Object" and "Paradise".
}

\section{Works Cited}

Abel, Elizabeth, Marianne Hirsch, and Elizabeth Langland. The Voyage In: Fictions of Female Development. Hanover, NH: University Press of New England, 1983.

Barros-del Río, María Amor. "Translocational Irish identities in Edna O’Brien's memoir Country Girl (2012)”. Gender, Place \& Culture 23.10 (2016): 1496-1507. 
Becerra Serrato, Diana B. Novel of Formation as a Representation of the Arousal of Consciousness of the Chicano People in Bless Me, Ultima. Master's dissertation, 2015.

Bolger, Dermot. The Picador Book of Irish Contemporary Fiction. London: Picador, 1993.

Bourke, Angela et al., eds. The Field Day Anthology of Irish Writing, Vols. IV-V. Cambridge: Cambridge University Press, 2002.

Byron, Kristine. "In the Name of the Mother ... : The Epilogue of Edna O'Brien's Country Girls Trilogy". Women's Studies 31.4 (2002): 447-465.

Cahalan, James. M. "Female and Male Perspectives on Growing up Irish in Edna O'Brien, John McGahern and Biran Moore”. Colby Quarterly 31.1 (1995): 55-73.

. Double Visions: Women and Men in Modern and Contemporary Irish Fiction. Syracuse, NY: Syracuse University Press, 1999.

Carlson, Julia. Banned in Ireland: Censorship and the Irish Writer. London: Routledge, 1990.

Colletta, Lisa and Maureen O'Connor, eds. Wild Colonial Girl: Essays on Edna O'Brien. Madison, WI: University of Wisconsin Press, 2006.

Coughlan, Patricia. "10 I Killing the Bats: O'Brien, Abjection, and the Question of Agency". Edna O'Brien: New Critical Perspectives. Eds. Laing, Kathryn, Sinéad Mooney, and Maureen O'Connor. London: Peter Lang, 2006. 171-195.

Cronin, John. “'The Dark' Is Not Light Enough: The Fiction of John McGahern”. Studies: An Irish Quarterly Review 58.232 (1969): 427-432.

Culler, Jonathan. Literary Theory: A Very Short Introduction. Oxford: Oxford University Press, 1997.

Dennison, Matthew. "Eternal Flame: Edna O'Brien at 80". The Telegraph. 29 November 2010. 6 June 2017. http://www.telegraph.co.uk/culture/books/8156501/Eternal-flameEdna-OBrien-at-80.html

Devine, Paul. "Style and Structure in John McGahern's The Dark". Critique: Studies in Contemporary Fiction 21.1 (1979): 49-58.

D'hoker, Elke. Irish Women Writers and the Modern Short Story. Basingstoke: Palgrave MacMillan, 2016.

Dougherty, Jane Elizabeth. "Nuala O'Faolain and the Unwritten Irish Girlhood". New Hibernia Review/Iris Éireannach Nua 11.2 (2007): 50-65.

Drisceoil, Donal O. “The Best Banned in the Land': Censorship and Irish Writing since 1950". The Yearbook of English Studies (2005): 146-160.

Dunleavy, Janet Egleson and Rachael Lynch. "Contemporary Irish Women Novelists". The British and Irish Novel since 1960. Ed. James Acheson. London: Palgrave Macmillan, 1991. 93-108.

DuPlessis, Rachel B. Writing beyond the Ending: Narrative Strategies of Twentieth-Century Women Writers. Bloomington, IN: Indiana University Press, 1985.

Eckley, Grace. Edna O'Brien. Lewisburg, PA: Bucknell University Press, 1974.

Fagan, Honor. "Globalised Ireland, or, Contemporary Transformations of National Identity?" The End of Irish History? Eds. Colin Coulter and Steve Coleman. Manchester: Manchester University Press, 2003. 110-121.

Ferguson, Mary A. "The Female Novel of Development and the Myth of Psyche". The Voyage In: Fictions of Female Development. Eds. Elizabeth Abel, Marianne Hirsch, and Elizabeth Langland. Hanover, NH: University Press of New England, 1983. 228243.

Fernández Vázquez, José S. Reescrituras Postcoloniales del Bildungsroman. Madrid: Verbum Editorial, 2003. 
Ferreira Pinto, Cristina. O Bildungsroman Feminino: Quatro Exemplos Brasileiros. São Paulo: Perspectiva, 1990.

Fogarty, Anne. "It was like a baby crying': Representations of the Child in Contemporary Irish Fiction". Journal of Irish Studies 30 (2015): 13-26.

Fraiman, Susan. Unbecoming Women: British Women Writers and the Novel of Development. New York: Columbia University Press, 1993.

Greenwood, Amanda. Edna O'Brien. Tavistock: Northcote House, 2003.

Hardin, James N. Reflection and Action: Essays on the Bildungsroman. Columbia, SC: University of South Carolina Press, 1991.

Harte, Liam. "Migrancy, Performativity and Autobiographical Identity". Irish Studies Review 14.2 (2006): 225-238.

Haule, James M. “Tough Luck: The Unfortunate Birth of Edna O'Brien”. Colby Quarterly 23.4 (1987): 216-224.

Huang, Shan-Yun. Growing Away: The Bildungsroman and Decolonization in Twentiethcentury Irish Literature. PhD thesis. University of Notre Dame, 2013.

Ingman, Heather. "Edna O'Brien: Stretching the Nation's Boundaries". Irish Studies Review 10.3 (2002): 253-265.

Kersnowski, Alice H. Conversations with Edna O'Brien. Jackson, MS: University Press of Mississippi, 2013.

Kiberd, Declan. Inventing Ireland: The Literature of the Modern Nation. Cambridge, MA: Harvard University Press, 1995.

Laing, Kathryn, Sinéad Mooney, and Maureen O'Connor, eds. Edna O’Brien: New Critical Perspectives. Dublin: Carysfort, 2006.

Mansouri, Shahriyar. The Modern Irish Bildungsroman: A Narrative of Resistance and Deformation. PhD thesis. University of Glasgow, 2014.

McMahon, Sean. “A Sex by Themselves: An Interim Report on the Novels of Edna O'Brien”. Eire-Ireland 2.1 (1967): 79-89.

McWilliams, Ellen. Margaret Atwood and the Female Bildungsroman. Burlington, VA: Ashgate Publishing, 2009.

Moloney, Caitriona and Helen Thompson. Irish Women Writers Speak Out: Voices from the Field. New York: Syracuse University Press, 2003.

Moretti, Franco. The Way of the World: The Bildungsroman in European Culture. London: Verso, 2000.

Morgan, Ellen. "Humanbecoming: Form and Focus in the Neo-Feminist Novel". Images of Women in Fiction: Feminist Perspectives. Ed. Susan Koppelmand Cornillon. Bowling Green, OH: Bowling Green University Popular Press, 1972. 183-205.

Nolan, Emer. Catholic Emancipations: Irish Fiction from Thomas Moore to James Joyce. New York: Syracuse University Press, 2007.

O’Brien, Edna. The Country Girls Trilogy and Epilogue. Houndsmills: Penguin, 1987.

O'Brien, Peggy. "The Silly and the Serious: An Assessment of Edna O'Brien". The Massachusetts Review 28.3 (1987): 474-488.

O'Callahan, Margaret. "Women and Politics in Independent Ireland, 1921-68". The Field Day Anthology of Irish Writing, V. Eds. Angela Bourke et al. Cork: Cork University Press, 2002. 120-176.

O'Leary, Eleanor. "Desperate Housewives: Social Change and the Desire for Modern Lifestyles in 1950s Ireland". Engendering Ireland: New Reflections on Modern History and Literature. Eds. Rebecca Anne Barr, Sarah-Anne Buckley, and Laura Kelly. Newcastle upon Tyne: Cambridge Scholars Publishing, 2015. 12-31. 
Pelan, Rebecca. "Edna O'Brien's 'Stage-Irish Persona': An 'Act' of Resistance”. The Canadian Journal of Irish Studies 19.1 (1993): 67-78.

Popot, Raymond. "Edna O'Brien's Paradise Lost". The Irish Novel in our Time. Eds. Patrick Rafroidi and Maurice Harmon. Lille: Publications de l'Université de Lille III, 1975. 253-65.

Rich, Adrianne. "Cartographies of Silence". The Dream of a Common Language: Poems 1974-7. New York: W.W. Norton \& Co., 1978. 16-20.

Rooks-Hughes, Lorna. "The Family and the Female Body in the Novels of Edna O'Brien and Julia O'Faolain”. The Canadian Journal of Irish Studies 22.2 (1996): 83-97.

Roth, Philip. "A Conversation with Edna O'Brien: 'The Body Contains the Life Story"”. New York Times. 18 November 1984. $30 \quad$ May 2017. http://www.nytimes.com/books/00/04/09/specials/obrien-roth.html

Schiff, Stacy. "Eternal Flame: Country Girl, A Memoir". Sunday Book Review. New York $\begin{array}{llllll}\text { Times. } & 10 & \text { May } & 2013 . & 10 & \text { June }\end{array}$ http://www.nytimes.com/2013/05/12/books/review/country-girl-a-memoir-by-ednaobrien.html?_r=0

Smyth, Gerry. The Novel and the Nation: Studies in the New Irish Fiction. London: Pluto Press, 1997.

St. Peter, Cristine. Changing Ireland: Strategies in Contemporary Women's Fiction. Basingstoke: Palgrave Macmillan, 2000.

Thompson, Helen. The Role of Irish Women in the Writings of Edna O'Brien: Mothering the Continuation of the Irish Nation. Lewiston, NY: Edwin Mellen Press, 2010.

Villacañas, Beatriz. Literatura Irlandesa. Madrid: Editorial Síntesis, 2010.

Woodward, Richard B. "Edna O'Brien: Reveling in Heartbreak". New York Times. 12 March 1989. 8 June 2017. http://www.nytimes.com/1989/03/12/magazine/edna-o-brienreveling-in-heartbreak.html

Maria Amor Barros-del Río is Assistant Professor at the University of Burgos, Spain. Her research focuses mainly on gender studies and contemporary fiction in English with a special interest in Irish fiction. Other fields of interest are critical pedagogy and second language teaching. She has published extensively in peer-reviewed journals such as Estudios Irlandeses, Gender, Place and Culture, Journal of Research in Gender Studies, International Journal of English Studies, English Language Teaching and The International Journal of English Studies. She is the author of Metáforas de su tierra: Breve historia de las mujeres irlandesas (2004) and El trabajo de las mujeres pobres (2010). Some of her contributions in collective works can be found in Postcolonial and Gender Perspectives in Irish Studies (ed. M. Morales Ladrón, 2007), Single Motherhood in 20th Century Ireland (eds. C. RambladoMinero and M. A. Pérez-Vides, 2006) and La Novela Irlandesa del siglo XX (ed. I. Praga Terente, 2005).

abarros@ubu.es 